\title{
Radikalisme Atas Nama Agama dalam Perspektif Intelektual Muda di Tengah Realitas Multikultural
}

\author{
Gina Lestari* \\ Universitas Gadjah Mada, Indonesia \\ E-mail: ginalestari0907334@gmail.com
}

\begin{abstract}
The reality of Indonesian multiculturalism is the fortune and wealth as far as its diversity is recognized, internalized, and responded with tolerance. If plurality becomes the separator that forms the symbol of a group and personal ego, then plurality becomes the cause of dispute, intolerance, and even radicalism. The cases of violence in the name of religion target all levels of society, including young intellectuals. This study aims to observe the scholar's perspective on radicalism in the name of religion in multicultural reality. The samples were 649 fourth semesters scholars in ITB, UNPAD, UPI, UIN Sunan Gunung Jati, UNPAS, UNISBA, and POLBAN in 2012. According to the research, most of the students have a good multicultural understanding. $65 \%$ of respondents have an awareness of accepting and appreciating differences, and $63 \%$ accept and appreciate differences in religious activities. Only 2\% (almost always) and 32\% (sometimes) commit acts of discrimination. However, half of the respondents (42\% slightly agree and 8\% agree) have an intolerant view. $21 \%$ of respondents slightly agree, and $3 \%$ agreed to view jihad as synonymous with violence. Surprisingly, $22 \%$ of respondents slightly agree, and $3 \%$ agreed to interpret jihad as terrorism. Moreover, $15 \%$ of respondents slightly agree, and $2 \%$ agreed to view suicide bombing as an act of jihad. Young intellectuals should have a clear understanding of jihad both etymologically or epistemologically. Overcoming the phenomenon of radicalism must depart from the core of the problems. One method is de-radicalization to straighten out a narrow-minded in a friendly, tolerant, peaceful, and humane way in the social, political, economic, and educational fields.
\end{abstract}

Keywords: Multiculturalism; Radicalism; Religion.

\begin{abstract}
Abstrak
Realitas multikultural Indonesia merupakan khasanah dan berkah sejauh kemajemukan disadari, dihayati dan disikapi dengan toleransi. Namun, jika kemajemukan menjelma menjadi pemisah yang melahirkan simbolisasi ego aku-kamu dan kita-mereka, maka perbedaan menjadi landasan perpecahan, intoleransi bahkan radikalisme. Kasus kekerasan atas nama agama menyasar semua lapisan masyarakat termasuk kaum intelektual muda (mahasiswa). Penelitian ini bertujuan mengamati perspektif mahasiswa tentang radikalisme atas nama agama yang muncul di tengah realitas multikultural. Sampel penelitian adalah 649 mahasiswa semester empat yang tersebar di kampus ITB, UNPAD, UPI, UIN Sunan Gunung Djati, UNPAS, UNISBA dan POLBAN pada tahun 2012. Berdasarkan hasil penelitian, sebagian besar mahasiswa memiliki pemahaman multikultural yang baik. Sebanyak $65 \%$ responden memiliki kesadaran dalam menerima dan menghargai perbedaan dan $63 \%$ responden menerima dan menghargai perbedaan dalam praktik peribadatan. Hanya $2 \%$ responden dan $32 \%$ responden yang selalu dan terkadang melakukan tindakan diskriminasi. Namun, setengah dari responden (42\% cukup setuju dan $8 \%$ setuju) memiliki pandangan intoleran. Sebanyak 21\% cukup setuju dan 3\% setuju memandang jihad identik dengan kekerasan dan $22 \%$ responden cukup setuju dan 3\% setuju menerjemahkan jihad identik dengan terorisme. Selain itu, $15 \%$ responden cukup setuju dan $2 \%$ setuju memandang bom bunuh diri sebagai tindakan jihad. Intelektual muda sudah sepatutnya memiliki pemahaman konteks jihad yang tidak melenceng baik secara etimologi maupun epistemologi. Cara mengatasi fenomena radikalisme harus berangkat dari penyelesaian terhadap sumber masalah. Salah satunya melalui deradikalisasi sebagai upaya meluruskan pemahaman yang sempit secara ramah, toleran, damai dan manusiawi baik dalam bidang sosial, politik, ekonomi maupun pendidikan.
\end{abstract}

Kata Kunci: Agama; Multikulturalisme; Radikalisme. 


\section{PENDAHULUAN}

Indonesia memiliki kondisi masyarakat yang paling majemuk di dunia, selain Amerika Serikat dan India. Indonesia merupakan lokus klasik, tempat terbaik atau rujukan bagi konsep masyarakat majemuk (Mahfud, 2011). Sedemikian kompleknya kemajemukan tersebut, Geertz memandang sulit melukiskan anatominya secara persis (Hardiman, 2002). Selain multietnis (Jawa, Batak, Bugis, Aceh, Flores, Bali, dst.), Indonesia juga menjadi arena pengaruh multimental dari kedatangan bangsa-bangsa lain ke nusantara. Sejarah mencatat banyak bangsa berdatangan ke nusantara seperti India, Cina, negara-negara Timur Tengah, Belanda, Portugis dan bangsa-bangsa lain yang membawa banyak paham dan kepercayaan seperti hindhuisme, buddhisme, konfusianisme, islam, kristen, kapitalisme dan lainnya.

Sebagai given yang patut kita syukuri, kondisi plural dan heterogen Indonesia merupakan potensi untuk membangun Indonesia menjadi negara multikultur yang besar "multikultural nation-state". Berdasarkan data sensus Indonesia's Population: Ethnicity and Religion in a Changing Political Landscape yang dilakukan oleh Institute of Southeast Asian Studies pada tahun 2000, terdapat lebih dari 300 kelompok etnik atau suku bangsa di Indonesia (Suryadinata, Arifin, \& Ananta, 2003). Menurut proporsi populasinya etnis di Indonesia terdiri dari 41,7\% Suku Jawa, 15,4\% Sunda, 3,7\% Tionghoa-Indo, 3,4\% Melayu, 3,3\% Madura, 3,0\% Batak, 2,7\% Minangkabau, 2,5\% Betawi, 2,5\% Bugis, 2,4\% Arab-Indo, 2,1\% Banten, 1,7\% Banjar, 1,5\% Bali, 1,3\% Sasak, 1.0\% Makassar, 0,9\% Cirebon, dan banyak suku-suku terpencil, terutama di Kalimantan dan Papua dengan populasi kecil yang hanya beranggotakan ratusan orang. Nasikun (2007) berpandangan bahwa kemajemukan Indonesia dapat dilihat dari dua cirinya yang unik, pertama secara horizontal berupa kesatuan-kesatuan sosial berdasarkan perbedaan suku bangsa, agama, adat, serta perbedaan kedaerahan, dan kedua secara vertikal antara lapisan atas dan lapisan bawah yang cukup tajam.

Realitas kemajemukan bangsa Indonesia diikat dalam prinsip persatuan dan kesatuan bangsa yang kita kenal dengan semboyan "Bhineka Tunggal Ika". Kemajemukan yang terintegrasi dalam kesatuan merupakan keunikan bangsa Indonesia yang harus disadari sebagai kekuatan dari berkah perbedaan. Namun, kemajemukan terkadang rawan berbenturan dengan persoalan yang menjadi bibit-bibit konflik dan perpecahan. Semakin besar jarak yang tercipta karena perbedaan dan intoleransi, semakin subur potensi konflik di masyarakat. Pelbagai indikasi yang dikhawatirkan yaitu munculnya organisasi kemasyarakatan, profesi, agama, dan organisasi lainnya yang melakukan tindakan-tindakan intoleransi.

Dewasa ini, Indonesia sebagai multicultural nation-state didera pelbagai persoalan yang dapat menggoncang kebhinekaan. Banyak terjadi tindakan kekerasan atas nama agama dalam pelbagai bentuk mulai dari fundamentalisme, radikalisme, hingga terorisme. Berkenaan dengan hal tersebut, agama sering kali menjadi legitimasi bagi manusia untuk bertindak intoleran terhadap orang lain. Burhani (2011) memandang bahwa ekstrimisme dan radikalisme banyak menjalar dan agama merupakan medan yang paling subur untuk tumbuhnya tindakan-tindakan tersebut. Tidak ada satu kelompok agama pun yang imun terhadap masalah ekstrimisme dan radikalisme.

Salah satu penelitian terkait radikalisme atas nama agama dari SETARA Institut di Jabodetabek \& Jawa Barat memaparkan fenomena yang cukup mengejutkan (Hasani, 2010). Pertama, Jawa Barat merupakan salah satu daerah yang pernah menjadi basis perjuangan merebut kekuasaan dan mendirikan Negara Islam melalui Gerakan Darul Islam. Basis utamanya adalah Garut, Tasikmalaya, Cianjur, dan Ciamis. Kedua, Jawa Barat dalam pemantauan kondisi kebebasan beragama atau berkeyakinan yang dilakukan SETARA Institute selalu menempati urutan pertama dengan jumlah pelanggaran tertinggi. Di tahun 2008 terjadi 73 pelanggaran dan di tahun 2009 terjadi 57 pelanggaran. Ketiga, radikalisme islam yang tumbuh di Jawa Barat (khususnya di wilayah Priangan Timur) memiliki keunikan tersendiri 
dibanding radikalisme di daerah lain. Aksi kekerasan yang terjadi di Garut, Tasikmalaya, dan Cianjur dilakukan oleh massa Islam yang diambil dari pesantren-pesantren. Sebagaimana diketahui Jawa Barat merupakan daerah religius yang memiliki banyak pesantren dalam ragam paham keagamaan.

Merujuk pada hasil penelitian tersebut, wilayah Jawa Barat memiliki sejarah gerakan organisasi garis keras dalam keagamaan. Menurut Hasani (2010) radikalisme merupakan katalisator yang bermuara dari tindakan intoleransi. Hal ini terjadi akibat kemarahan atas ketimpangan sosial di masyarakat. Penyebab utamanya, selain genealogi masa lalu, juga akibat frustrasi atas ketidakadilan sosial yang berdampak pada apatisme sehingga memicu radikalisme atas nama agama. Peristiwa intoleransi lainnya dipaparkan Hiariej (2010) bahwa serangkaian bom meledak dalam waktu yang nyaris bersamaan di dalam atau di sekitar 38 gereja Katolik dan Protestan di 11 kota di Sumatra, Jawa dan Nusa Tenggara Barat (NTB). Jauh sebelum kasus-kasus kekerasan di atas terjadi, gerakan-gerakan radikal di Indonesia sudah terjadi sejak 1970an dan 1980an yang berakar pada gerakan DI/TII di beberapa wilayah Jawa Barat, Jawa Tengah, Sumatra (Aceh), Kalimantan, dan Sulawesi Selatan.

Terorisme dan radikalisme khususnya radikalisme atas nama agama merupakan ancaman bagi keutuhan Negara Kesatuan Republik Indonesia (NKRI). Ironisnya kasus-kasus kekerasan atas nama agama ini menyasar semua lapisan masyarakat tanpa terkecuali. Tidak ada satu golongan masyarakat pun yang imun akan tindakan intoleransi, termasuk intelektual muda (mahasiswa). Menurut Azra (2011) dari masa ke masa di lingkungan kampus hampir selalu ada kelompok radikal dan ekstrem, baik kanan maupun kiri. Kampus merupakan ranah publik dengan pelbagai aktivitas akademik yang rentan menjadi sasaran pengaruh serta infiltrasi paham, wacana, dan gerakan radikalisme agama dari luar. Menurut Ketua Forum Ulama Umat Indonesia (FUUI) KH Ali M., Athian (2011) dari empat kampus (ITB, UNPAD, POLBAN dan UPI), mahasiswa ITB menjadi yang terbanyak direkrut sebagai anggota NII oleh aktivitis NII gadungan/ NII KW IX. KH Ali M., Athian (2011) juga memaparkan berdasarkan data FUUI tahun 20022003, jumlah mahasiswa ITB yang direkrut oleh NII Gadungan mencapai 200 orang. Faktanya, serangkaian kasus cuci otak NII di beberapa kampus yang terjadi pada pertengahan tahun 2010 disinyalir dilakukan oleh gerakan NII KW IX. Mahasiswa sebagai kaum intelektual muda justru menjadi sasaran kelompok intoleran yang menyusup ke lingkungan kampus. Jika tidak dikaji akar permasalahannya, sangat dikahawatirkan hal serupa akan berulang di kemudian hari.

Berdasarkan pemaparan di atas, penulis tertarik melakukan pengamatan mendalam untuk mengkaji perspektif intelektual muda (mahasiswa) tentang radikalisme atas nama agama dalam praming multikulturalisme. Penelitian ini menggunakan metode deskriptif studi kelanjutan (follow-up study) dengan pendekatan kuantitatif dan kualitatif dengan pola "the dominant-less dominant" dari Creswell (1994). Pendekatan kuantitatif sebagai dominant dan pendekatan kualitatif sebagai less dominant. Perspektif multikultural sebagai variabel independent dan radikalisme atas nama agama sebagai variabel dependent (Y). Sampel dalam penelitian diambil dengan menggunakan rumus Isaac dan Michael (Sugiyono, 2011) diperoleh sampel sebanyak 649 mahasiswa semester empat yang tersebar di kampus ITB, UNPAD, UPI, UIN Sunan Gunung Djati, UNPAS, UNISBA dan POLBAN. Teknik pengumpulan data menggunakan angket model summated rating scale Likert dan teknik wawancara berdasarkan tahaptahap dari Miles dan Huberman dilanjutkan dengan pengolahan data statistik dan rekap wawancara (Sugiyono, 2011).

\section{HASIL DAN PEMBAHASAN}

Pengumpulan data kuesioner dijabarkan melalui 47 butir pertanyaan yang mewakili perspektif multikultural dan radikalisme atas nama agama dengan validitas yang sigtifikan pada setiap butir soal. 
Berdasarkan uji reliabilitas pada kuesioner, diperoleh $11 \%$ soal reliabilitas sangat tingggi, $27 \%$ reliabilitas tinggi dan $62 \%$ reliabilitas sedang. Adapun uji sebaran data dan normalitas data dapat diamati pada gambar 1 dan 2.

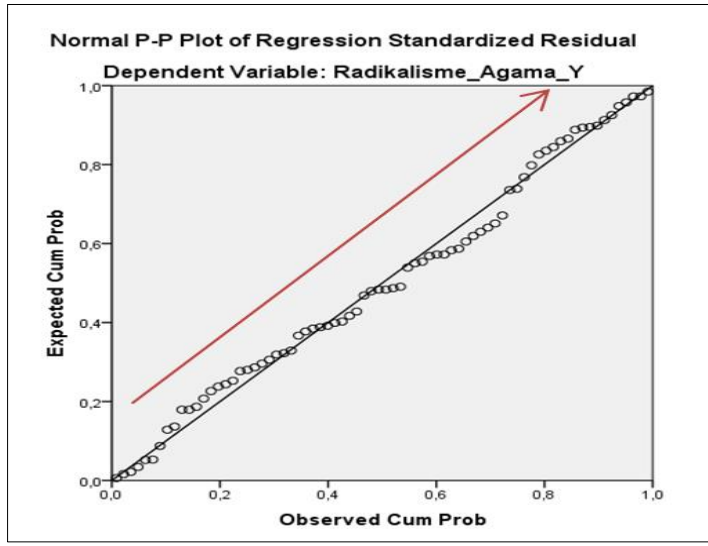

Gambar 1. Kurva P-Plot Normalitas Data

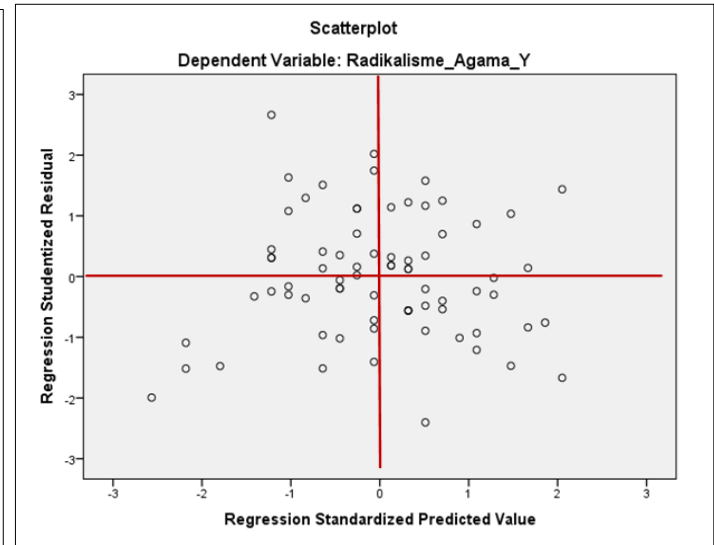

Gambar 2. Scatterplot Sebaran Data

Berdasarkan analisis kurva P-Plot pada gambar 1 dapat dilihat bahwa data menyebar disekitar diagram dan mengikuti model regresi sehingga dapat ditarik kesimpulan bahwa data penelitian terdistribusi normal atau memenuhi uji normalitas. Berdasarkan output scatterplot pada gambar 2, titiktitik pada gambar menyebar secara acak dan tidak membentuk pola tertentu yang jelas. Sehingga, dapat disimpulkan bahwa data menyebar secara acak dan tidak terjadi heteroskedastisitas. Berdasarkan pengukuran tersebut, pengambilan sampel, kuesioner penelitian dan penyebaran data penelitian dilakukan secara valid dan terukur. Sehingga, data yang dihasilkan dapat menggambarkan keterwakilan yang valid tentang perspektif intelektual muda tentang radikalisme atas nama agama dalam framing multikulturalisme.

\section{Perspektif Multikultural Kaum Intelektual Muda}

Gerakan multikultural menurut Bhikhu Parekh diperkenalkan pertama kali di Kanada dan Australia kemudian di Amerika Serikat (Sirry, 2002), Inggris, Jerman, dan negara lainnya pada 1970-an. Inti dari multikulturalisme adalah kesediaan menerima kelompok lain secara sama sebagai kesatuan, tanpa memedulikan perbedaan budaya, etnik, gender, bahasa ataupun agama. Konsep multikulturalisme merupakan konsep keberagaman budaya dalam perspektif kesetaraan. Akar kata multikulturalisme adalah kebudayaan, secara etimologis, multikulturalisme dibentuk dari kata multi (banyak), kultur (budaya), dan isme (aliran/paham). Secara hakiki, dalam kata ini terkandung pengakuan akan martabat manusia yang hidup dalam komunitasnya dengan kebudayaannya masing-masing yang unik (Mahfud, 2011).

Setiap individu dalam masyarakat memiliki kebutuhan untuk diakui (politics of recognition) dan kebutuhan untuk diterima, sehingga terbentuk identitas dan penghargaan tertentu secara sosial. Kesediaan menerima muncul dari kesadaran atas perbedaan yang tumbuh dari interaksi harmonis antar kelompok yang hidup bersama. Menurut Azra pentingnya penghargaan terhadap perbedaan merupakan nilai-nilai dan prinsip-prinsip yang dipromosikan oleh gerakan sosio-intelektual bernama multikulturalisme (Zubaedi, 2012). Orientasi gerakan ini adalah kehendak untuk membawa masyarakat 
dalam suasana rukun, damai, egaliter, toleran, saling menghargai dan menghormati tanpa ada konflik dan kekerasan dan tanpa menghilangkan kompleksitas perbedaan yang ada.

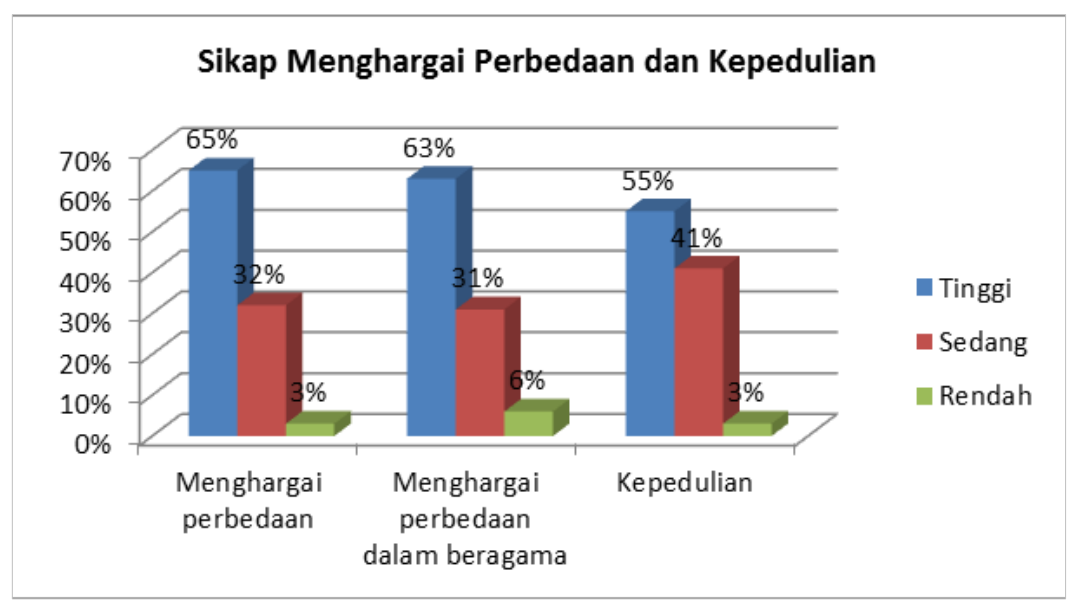

Gambar 3. Diagram sikap menghargai perbedaan dan kepedulian

Berdasarkan diagram gambar 3, sikap menghargai perbedaan yang ditunjukkan responden meliputi sikap mendengarkan, menghargai dan menerima perbedaan pendapat, serta memandang perbedaan sebagai kewajaran. Adapun sikap menghargai perbedaan dalam beribadah/ beragama meliputi sikap menerima perbedaan dalam praktik peribadatan, memandang perbedaan agama sebagai hal yang lumrah serta menghargai pandangan semua agama mengajarkan kebenaran. Berkaitan dengan konsep kebenaran dalam agama, setiap agama memiliki konsep kebenaran tersendiri namun dalam beberapa hal agama memiliki nilai kebenaran secara universal. Nilai universal ini diantaranya nilai kemanusiaan yang menurut Frans Magnis Suseno mewujud dalam unsur-unsur budaya demokrasi, nondiskriminatif, serta pengakuan martabat manusia tanpa membedakan SARA (Komalasari, 2008). Berdasarkan data penelitian, bentuk kepedulian yang ditunjukkan berupa kesadaran menolong sebagai bentuk tanggung jawab sesama manusia. Selain itu, diamati pula ketertarikan dan kepedulian responden terhadap masalah sosial di lingkungannya. Berdasarkan pengukuran tersebut, diperoleh hasil yang baik berkaitan dengan sikap menghargai dan kepedulian intelektual muda.

Menurut Tim Departemen Agama RI (2003), output dari pengembangan wawasan multikultural adalah terbentuknya masyarakat yang mengakui perbedaan, saling menghargai, menghormati secara tulus, komunikatif, dan terbuka, tidak saling curiga, memberi tempat terhadap keragaman keyakinan, tradisi, adat, maupun budaya. Sehingga, terbentuk kerjasama sosial dan tolong menolong secara tulus sebagai perwujudan rasa kemanusiaan. Senada dengan hal tersebut, Musa Asy'arie berpandangan bahwa multikulturalisme adalah kearifan untuk melihat keanekaragaman budaya sebagai realitas fundamental dalam kehidupan bermasyarakat (Mahfud, 2011). Kearifan tumbuh jika ada kemauan untuk membuka diri dan menjalani kehidupan bersama dengan realitas plural yang kodrati.

Berdasarkan diagram pada gambar 4, sebanyak 66\% intelektual muda melakukan tindakan diskriminasi yang rendah, tindakan pemaksaan yang rendah (63\%), serta pandangan kekerasan yang rendah (71\%). Pengukuran tindakan diskriminasi meliputi pertemanan berdasarkan status ekonomi dan sosial, membedakan orang lain berdasarkan perbedaan SARA, ekonomi, pendidikan dan status sosial. Tindakan pemaksaan diukur dari pandangan kekerasan sebagai bentuk hukuman, kekerasan sebagai penyelesaian masalah dan memandang kesalahan harus dimusnahkan. Multikulturalisme merupakan 
konsep yang menumbuhkan kesadaran akan perbedaan, penghargaan, toleransi, non-diskriminasi hingga menciptakan suasana non-konflik dan non-kekerasan. Sehingga, tindakan diskriminasi, pemaksaan dan kekerasan adalah antitesa dari multikulturalisme. Dari konsepsi tersebut, menurut Zubaedi (2012) multikulturalisme merupakan suatu konsep yang ingin membawa masyarakat dalam kerukunan dan perdamaian, tanpa ada konflik dan kekerasan, meski di dalamnya ada kompleksitas perbedaan.

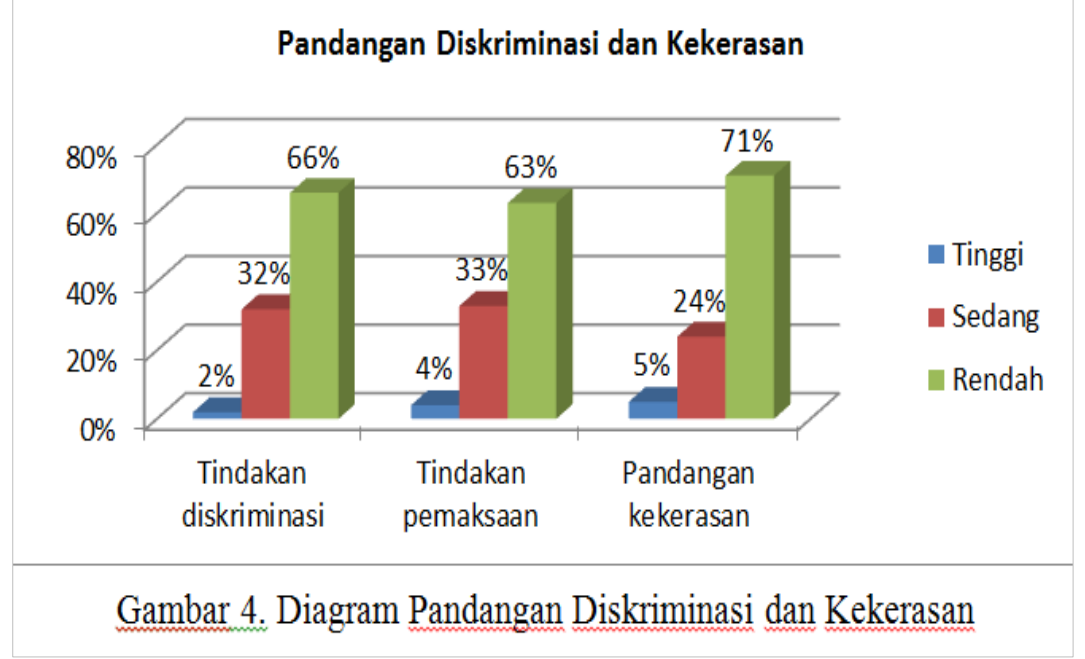

Gambar 4. Diagram Pandangan Diskriminasi dan Kekerasan

Berdasarkan hasil penelitian, sebagian besar intelektual muda memiliki sikap menghargai perbedaan dan kepedulian yang tinggi serta melakukan tindakan diskriminasi, pemaksaan dan tindakan kekerasan yang rendah. Dari data tersebut, dapat disimpulkan bahwa sebagian besar intelektual muda memiliki wawasan multikultural yang baik. Hal tersebut terlihat dari sebagian besar responden (intelektual muda) yang mengenal, memahami dan menerapkan nilai-nilai dan prinsip-prinsip multikultural berupa toleransi, penghargaan terhadap perbedaan, kepedulian, non-konflik dan nonkekerasan. Nilai-nilai tersebut merupakan model terbentuknya wawasan multikultural pada generasi muda. Hal tersebut sejalan dengan Bank yang memaparkan bahwa wawasan multicultural dapat membentuk gaya hidup, pengalaman sosial, identitas pribadi, serta menjadi kesempatan-kesempatan pendidikan dari individu, kelompok maupun negara (Albone, 2006).

\section{Radikalisme Atas Nama Agama di Lingkungan Kampus}

Agama sebagai pedoman hidup mengajarkan kedamaian dan toleransi kepada pemeluknya. Namun, konflik agama sering kali muncul sebagai benturan perbedaan dari keterbatasan pemeluk agama dalam mentransformasi nilai-nilai dan prinsip-prinsip agama yang dianutnya. Faktor lain penyebab konflik antar umat beragama menurut Naim dan Sauqi (2017) adalah paradigma keberagamaan yang eksklusif. Implikasi dari eksklusivitas beragama adalah terbentuk pribadi yang antipasti, subjektivitas yang tinggi dalam memandang agama lain, kepribadian tertutup, menutup ruang dialog dengan pemeluk agama lain, merasa agama dan alirannya saja yang benar yang lainnya salah dan dianggap sesat. Meyakini kebenaran agama yang dianut adalah hal mutlakyang harus ada dalam berkeyakinan. Namun, hal tersebut bukan alasan menjustifikasi agama dan keyakinan orang lain menyimpang dan sesat. Cara pandang tersebut justru dapat memicu tindakan-tindakan diskriminasi dan intoleransi yang banyak mengarah pada gerakan radikalisme atas nama agama. 
Radikalisme (at tatharuf) merupakan sikap berlebihan dalam sesuatu, dekat dengan kebinasaan dan bahaya, serta jauh dari keselamatan (Qardhawi, 2009). Tindakan radikalisme ini dilandasi masalahmasalah mendasar di masyarakat baik berupa masalah sosial, ekonomi, politik maupun persoalan teologis (Bin-Saat, 2007). Tujuan mendasar dari gerakan ini adalah perubahan sosial dan politik secara cepat dan menyeluruh yang dilakukan dengan menggunakan cara-cara tanpa kompromi dan bahkan kekerasan (Azra, 2002). Selain kondisi sosial dan kesenjangan ekonomi (faktor eksternal), radikalisme juga dipengaruhi oleh ketidak mampuan individu dalam memahami perubahan yang demikian cepat (faktor internal). Keadaan pemerintahan yang tidak menentu disinyalir memperburuk cara pandang radikal tersebut. Menurut Azra (2002) tindakan radikal didorong oleh pandangan bahwa perubahan secara damai tidak akan efektif dan berhasil, karena terdapat struktur-struktur sosial-politik tertentu yang demikian mapan sehingga dipandang tidak ada jalan kecuali radikal.

Dari pelbagai pandangan tersebut, radikalisme atas nama agama bukan konsep yang melekat pada agama tertentu, tidak ada satu agama pun yang imun terjangkit paham radikal. Ideologi radikal bisa tumbuh pada penganut agama manapun sejauh aktivitas keagamaannya sedemikian eksklusif, intoleran dan diskriminatif. Sehingga, radikalisme bukan sebuah ajaran agama melainkan argument atau paradigma yang menjadi ideologi gerakan kelompok radikal. Graham C. Kinloch memandang ideologi sebagai argumen dari pandangan atau paradigma sosial sekelompok orang untuk menjustifikasi tindakan mereka (Amirsyah, 2012). Karakteristik dasar ideologi mengandaikan kecenderungan intoleran terhadap epistemologi berfikir ideologi yang lain. Sehingga, jika radikalisme dijadikan sebagai ideologi gerakan yang dilegitimasi oleh pemahaman agama, maka tindakan kekerasan bahkan terorisme dibolehkan bahkan dipandang sebagai bentuk perjuangan.

Mbai berpandangan bahwa ideologi radikal merupakan penyebab dari maraknya aksi teror di Indonesia (Umar, 2010). Sejalan dengan itu, menurut Ted Robert Gurr selain disebabkan radikalisme atas nama agama, terorisme juga disebabkan oleh munculnya rasa tertindas dan ketidakadilan yang terus menerus, tertekan dengan sistem yang korup, saparatisme serta fanatisme ideologi, ras maupun etnik (Zubaedi, 2012). Pelaku teror menjadi orang yang dibutakan rasa marah, dendam dan kebencian yang membuat mereka menjadi keras dan tidak manusiawi (Suseno, 2006). Terorisme yang disebabkan radikalisme atas nama agama merupakan wujud dari akumulasi kemarahan, kebencian, rasa dendam, merasa tertindas dan berbagai perspektif keagamaan yang eksklusif. Sehingga, paradigma sosial dan keagamaan individu sedemikan berpengaruh terhadap perspektif dan tindakannya di masyarakat. Berkaitan dengan hal tersebut, hasil penelitian perspektif intelektual muda tentang radikalisme atas nama agama dapat diamati pada diagram berikut;

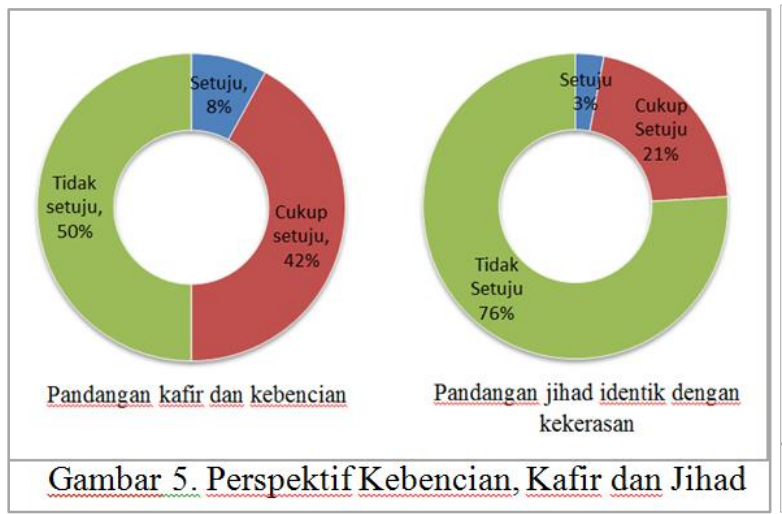

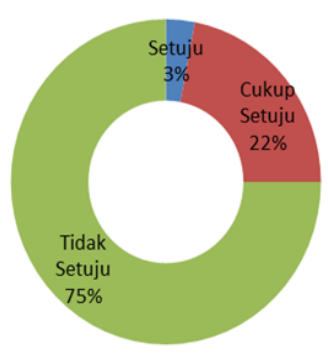

Jihad identik dengan terorisme

Gambar 6. Perspektif Jihad dan Terorisme

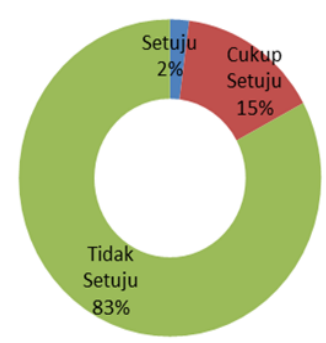

Bom bunuh diri adalah jihad 
Berdasarkan diagram pada gambar 5 , setengah dari responden mahasiswa, $42 \%$ cukup setuju dan 8\% setuju terhadap pandangan kafir dan kebencian. Hasil penelitian menunjukkan bahwa perspektif intoleran dan kebencian muncul di kalangan intelektual muda. Seperempat responden mahasiswa, 21\% cukup setuju dan 3\% setuju, terhadap pernyataan penelitian. Hal ini menunjukkan masih banyak mahasiswa sebagai kaum intelektual muda yang memiliki perspektif tentang jihad yang keliru. Menurut Azra (2002) jihad mengandung makna yang sangat luas, jihad akbar yakni jihad melawan hawa nafsu dan jihad asghar yakni perang melawan musuh-musuh islam dan muslimin. Jihad juga mengandung pengertian setiap usaha sungguh-sungguh yang dilakukan dalam amal perbuatan baik apa saja $f(i$ sabilillah), yang diniatkan sebagai ibadah kepada Alloh SWA. Pemahaman konteks jihad yang lebih universal tanpa menyimpang dari nash aslinya perlu dimiliki oleh kaum intelektual muda. Selain itu, kaum intelektual muda khususnya muslim perlu menerapkan bentuk ibadah yang bukan hanya hablumminalloh tetapi didukung juga oleh hablumminannas sehingga tercipta keteraturan dan kedamaian hidup berdampingan antar umat beragama.

Istilah jihad secara konfrontatif hampir selalu diidentikan dengan konsep perang dalam agama Islam. Konsep dan pemahaman jihad menyered islam sebagai agama kekerasan, jauh dari ajaran yang dibawa Rosululloh. Pemahaman tersebut tercipta dari persepsi masyarakat terhadap pelbagai kasus radikalisme atas nama agama dalam pelbagai bentuk di Indonesia. Berkenaan dengan ini, Hiariej (2010) memandang bahwa bentuk aksi kolektif kelompok Islam radikal cukup beragam, dari penggunaan kekerasan dan serangan mamatikan hingga pawai massa dan protes damai. Dari semua gerakan yang banyak muncul, baik gerakan dakhwah, jihad, maupun gerakan radikal, faham yang paling dihawatirkan adalah radikalisme atas nama agama yang mengarah pada terorisme. Manifestasi dari radikalisme atas nama agama yang paling membahayakan adalah terorisme. Keduanya memiliki tipe penggunaan doktrin dan kerangka jihad yang melenceng.

Hasil penelitian perspektif intelektual muda tentang jihad dan terorisme dapat diamati pada gambar 6 . Sebanyak $22 \%$ responden cukup setuju dan $3 \%$ responden setuju menerjemahkan jihad identik dengan terorisme. Selain itu, 15\% dan 2\% responden cukup setuju dan setuju memandang bom bunuh diri sebagai bentuk tindakan jihad. Mahasiswa sebagai intelektual muda sudah sepatutnya memiliki sudut pandang dan pemahaman konteks jihad yang benar dan tidak melenceng baik secara etimologi maupun epistemologinya. Pemahaman yang keliru tentang jihad dan terorisme berkaitan dengan pemahaman yang sempit, keterbatasan pengetahuan dan tidak membuka ruang diskusi untuk memahaminya. Berdasarkan Fatwa MUI No. 3 Tahun 2004 tentang terorisme (Amirsyah, 2012), perbedaan antara terorisme dengan jihad adalah dari sifatnya. Terorisme sifatnya merusak (ifsad) dan anarkhis/chaos (faudha) dengan tujuan menciptakan rasa takut dan atau menghancurkan pihak lain, dilakukan tanpa aturan dan sasaran tanpa batas. Jihad sifatnya melakukan perbaikan (ishlah) sekalipun dengan cara peperangan. Tujuannya menegakkan agama Alloh dan atau membela hak-hak pihak yang teraniaya (terzholimi). Dilakukan dengan mengikuti aturan yang ditentukan oleh syari'at dengan sasaran musuh yang sudah jelas.

Jihad bukan tindakan yang dilakukan dengan membabibuta, merusak, dan membunuh saudara seiman. Bahkan dalam ajaran Islam, membunuh seorang manusia apalagi saudara seiman seperti membunuh semua umat manusia karena itu islam melarang keras saling melukai, bertikai, bahkan membunuh. Islam sejatinya merupakan agama yang membawa kedamaian dan penuh dengan kasih sayang. Aksi teror dengan cara-cara kekerasan terutama pengeboman merupakan tindakan yang tidak manusiawi. Aksi seperti ini tentu tidak ada kaitannya sama sekali dengan aliran suatu agama tertentu termasuk agama Islam. Munculnya terorisme yang dilakukan oleh segelintir pemeluk Islam seringkali 
dikaitkan dengan pemahaman konteks jihad dan pemahaman mati syahid yang salah. Menurut Azra (2002) jihad dalam pengertian perang sering diasosiasikan atau bahkan diidentikkan pihak Barat dengan teror dan terorisme. Justifikasi moral tindakan jihad dan kesesuaiannya dengan aspek-aspek agama islam menjadi ukuran sejauh mana jihad dapat berubah menjadi teror dan terorisme.

Kasus yang muncul berkenaan dengan tindakan intoleran di Indonesia di antaranya kasus cuci otak NII di lingkungan kampus pada pertengahan tahun 2009. Gerakan cuci otak NII ini merupakan bentuk radikalisme atas nama agama yang berwujud radikalisme dalam pikiran atau fundamentalisme (Sabirin, 2004). Radikalisme yang bersifat pemikiran mengutamakan pemikiran dan pendapat dengan kemungkinan yang buruk daripada yang baik sehingga menanamkan kebencian dan intoleran (Qardhawi, 2009). Maraknya kasus cuci otak NII pada awal tahun 2005 hingga pertengahan 2009, disinyalir terkait dengan gerakan DI/TII pada masa silam. Gerakan ini selain menyasar masyarakat umum juga menyusupi lingkungan pendidikan seperti kampus dan sekolah. Menurut data dari Forum Ulama Umat Indonesia/ FUUI, KH. Athian Ali M (2011), data mahasiswa salah satu universitas negeri di Kota Bandung yang direkrut NII pada tahun 2002-2003 mencapai 200 orang, belum ditambah data kasus yang terjadi tahuntahun setelahnya hingga akhir 2009.

Berdasarkan hasil wawancara dengan Ketua NII Crisis Center, Ken Setiwan, gerakan NII merupakan wujud ketidakpuasan terhadap pemerintah sebagai warisan ideologi gerakan DI TII Kartosuwiryo tahun 1949. Pada tahun 1979, dibentuk beberapa organisasi-organisasi radikal di antaranya Komendemen Wilayah 9 atau yang lebih dikenal dengan istilah NII KW 9. Penyebaran paham radikal melalui cuci otak NII KW 9 terhadap banyak mahasiswa dilakukan lewat pendekatan agama. Calon korban diajak berdialog tentang kondisi kenegaraan, ditanamkan keraguan terhadap negara dan pemerintah karena tidak menjalankan syariat Islam, menukil berbagai ayat Al Qur'an serta hadis yang diambil secara sepotong-sepotong hingga ditanamkan keraguan terhadap agamanya. Dengan doktrindoktrin semacam itu, calon korban disuruh untuk bersyahadat lagi dan mengikuti ajaran mereka. Semua orang di luar gerakan mereka adalah kafir sehingga halal harta bahkan darahnya termasuk orang tua sendiri. Setelah menjalani proses bai'at dan menjadi anggota, sering kali korban menggunakan semua uangnya bahkan mengambil uang orang tuanya untuk mendanai apa yang menurut korban dipandang sebagai jihad (Setiawan, Wawancara, 2012)

Sebelum direkrut, calon korban sudah diidentifikasi secara detail latar belakangnya. Beberapa faktor yang menjadi pertimbangan anggota NII dalam merekrut mahasiswa di antaranya; (1) merekrut mahasiswa baru dengan modus membantu mengenalkan lingkungan baru di dunia kampus baik dalam berorganisasi, perkuliahan maupun proses sosialisasi lainnya (2) menghindari mahasiswa dari latar belakang keluarga TNI dan Polri, (3) biasanya mahasiswa dengan pemahaman keagamaan yang kurang namun memiliki keinginan untuk memperdalam Islam, (4) di beberapa kasus, merekrut mahasiswa yang menjadi ketua dalam suatu organisasi atau perkumpulan tertentu, (5) mahasiswa yang cenderung 'penyendiri' sehingga ketika didekati merasa ada teman yang peduli kepadanya, (6) memiliki latar belakang ekonomi yang cukup mapan, (7) melakukan pendekatan secara personal dan persuasif, misalnya melihat kesamaan latar belakang kedaerahan, keilmuan, gerakan keorganisasian di kampus dan yang paling diutamakan kesamaan jenis kelamin (Setiawan, Wawancara, 2012).

Salah satu kasus yang sedang ditangani NCC ketika itu adalah korban yang berprofesi sebagai bidan direkrut NII KW 9 sejak masih kuliah. Biasanya anggota NII menikah dengan anggota NII yang lain, namun korban W ini dijodohkan oleh orang tuanya. Korban menganggap pernikahannya adalah perbuatan dosa, penghasilannya dari pemerintah adalah uang haram karena berasal dari pemerintah yang kafir, tidak menerapkan hukum-hukum Islam. Harta pribadi bahkan harta keluarga halal untuk diinfakkan mendanai 
gerakan NII KW 9 dengan dalih berjihad (menurut pandangan gerakan ini). Ken Setiawan mengungkapkan, dana dari infak dan sodaqoh anggota yang dia kumpulkan ketika masih menjadi anggota gerakan NII KW 9 pada tahun 2000 bisa mencapai 1,4 milyar dalam satu bulan. Uang yang seharusnya untuk membayar kuliah, keperluan rumah tangga, bahkan uang dari hasil menipu orang tua dianggap halal diinfakkan untuk kepentingan pergerakan NII KW 9 (Setiawan, Wawancara, 2012).

Dari masa ke masa di lingkungan kampus hampir selalu ada kelompok radikal dan ekstrem, baik kanan maupun kiri. Kebebasan akademis dan kebebasan sosial di kampus menjadi salah satu faktor sulitnya pemimpin perguruan tinggi mengontrol mahasiswa mereka, apalagi alumni yang telah menyebar di masyarakat. Kampus sebagai ranah publik tidak imun terhadap pelbagai pengaruh serta infiltrasi paham, wacana, dan gerakan dari luar termasuk gerakan radikal (Azra, 2011). Radikalisme atas nama agama di kampus harus ditangani bersama antara pihak kampus, pemerintah, masyarakat umum, dan pihak-pihak terkait. Solusi yang dipilih harus bersifat konstruktif untuk membangun individu, memajukan masyarakat, memperbaiki pemahaman ajaran agama, dan memakmurkan masyarakat secara keseluruhan. Qardhawi (2009) memandang, fenomena radikalisme dan kekerasan yang melibatkan pemuda tidak bisa diatasi dengan kekerasan dan intimidasi. Kekerasan hanya akan meningkatkan radikalisme sementara intimidasi hanya akan membuat mereka semakin nekat.

Menurut Singh dan Mulkhan (2012) meredam aksi radikal tidak cukup dilakukan hanya dengan menangkap dan menghukum pelakunya, melainkan memerlukan pendekatan budaya yang komprehensif. Masalah yang bermuara pada ideologi harus diatasi dengan dialog konstruktif, pendekatan yang persuasif, memahami sikap dan pemikiran mereka dan berupaya menghilangkan jurang pemisah sehingga konsep dan pemikiran menjadi jelas. Tujuannya agar simpul-simpul perselisihan menjadi terbuka serta mengutamakan keadilan dan kedamaian. Usaha memerangi terorisme dalam bentuk apapun seharusnya tidak dilakukan dengan cara-cara kekrasan, cara yang dipilih harus berangkat dari penyelesaian terhadap akar atau sumber masalah/core of the problems (Azra, 2002). Menurut Sirry (2002) banyak faktor yang menyebabkan kultur perdamaian belum built-in dalam masyarakat Indonesia. Pertama, masih dominannya pemahaman keagamaan yang eksklusif. Kedua, tidak serius dalam melakukan dialog lintas agama dan kultural. Ketiga, terabaikannya pesan-pesan perennial keagamaan (pesan universal agama tergadaikan demi kepentingan politik). Diperlukan penggalian terhadap pesan-pesan parenial kesucian agama untuk menuntun umat manusia menuju kehidupan yang damai dan bermakna.

Belajar dari pengalaman Indonesia selama lebih dari 50 tahun menangani berbagai kasus radikalisme yang terjadi, telah membuktikan bahwa pendekatan kekerasan bukan solusi yang tepat menyelesaikan radikalisme dan terorisme. Pengalaman kasus DI/TII yang terjadi di masa silam merupakan pelajaran berharga bahwa cara-cara kekerasan bukan solusi yang tepat untuk menyelesaikan masalah moral dan ideologi hingga keakarnya (Amirsyah, 2012). Ideologi kekerasan tetap hidup sampai sekarang dan bukan tidak mungkin akan muncul kembali dengan kekuatan yang lebih membahayakan. Pendekatan dengan cara kekerasan sangat tidak efektif bahkan memiliki efek samping di masa mendatang. Sementara itu, pendekatan lunak (soft power) seperti deradikalisasi tidak akan berdampak negatif, dilakukan berkelanjutan, sistematis dan terarah.

Deradikalisasi merupakan suatu proses meluruskan pemahaman yang sempit menjadi bisa menerima, saling perhatian dan toleran. Pendekatan ini dilakukan dengan berbagai cara yang manusiawi baik dalam bidang sosial, politik, ekonomi maupun pendidikan. Menurut Jeffrie Geovanie deradikalisasi merupakan upaya untuk menanamkan pemahaman agama yang ramah dan damai dalam perspektif kebhinekaan sehingga setiap pemeluk agama mau dan mampu menerima perbedaan dengan tulus dan lapang dada (Amirsyah, 2012). Jika setiap umat beragama memiliki wawasan multikultural, maka akan 
tumbuh dalam dirinya sikap toleran, menghargai dan menghormati perbedaan keyakinan, tradisi, adat dan budaya sehingga tumbuh keterbukaan dan rasa saling menghargai terhadap pandangan orang lain.

Implementasi deradikalisasi bagi kalangan intelektual muda di dunia kampus difokuskan pada penanaman wawasan multikultural untuk menumbuhkan sikap toleran, saling menghargai, penerimaan atas perbedaan dan egaliter. Hal tersebut dapat dilakukan baik melalui perkuliahan maupun di luar perkuliahan. Dalam perkuliahan, implementasi deradikalisasi disisipkan pada mata kuliah Pendidikan Kewarganegaraan dan Pendidikan Agama. Namun sejatinya, pendekatan pendidikan yang humanis dan toleran harus diterapkan dalam semua bidang ilmu bukan hanya muatan materi Pendidikan kewarganegaraan dan Pendidikan agama. Sikap humanis dan toleran dapat dikembangkan melalui pendidikan yang berbasis nilai kemanusiaan baik dalam pelbagai materi ajar maupun dalam proses pembelajaran (Komalasari, 2008).

Selain itu, diluar perkuliahan, harus dibuat kebijakan-kebijakan yang mendukung terbentuknya iklim kampus yang berwawasan multikultural. Hal tersebut mutlak dilakukan sebagai langkah preventif berkambangnya paham-paham radikal di dunia kampus. Menurut Sirry (2002) beberapa faktor yang menyebabkan kultur perdamaian belum terbangun dengan kokoh di Indonesia diantaranya; (1) dominannya pemahaman keagamaan yang eksklusif, (2) tidak serius dalam melakukan dialog lintas agama dan kultural, (3) terabaikannya pesan-pesan perennial keagamaan dimana pesan universal agama tergadaikan demi kepentingan politik. Kelemahan-kelemahan yang dipaparkan Sirry tersebut sangat kontras dengan semakin gencarnya penyebaran benih-benih radikalisme dalam pelbagai cara mulai dari hiburan, televisi, internet bahkan melalui oknum pendidikan (kasus cuci otak NII KW IX). Salah satu kebijakan konkret kampus yang dapat dilakukan diantaranya yaitu mentoring keagamaan. Mentoring keagamaan dilakukan untuk menguatkan pondasi mahasiswa dalam menanamkan pemahaman keagamaan yang toleran, jauh dari paham absolutisme, eksklusivisme, fanatisme, ekstrimisme dan agresivisme. Selain itu, system bimbingan teman sebaya antar mahasiswa pada proses mentoring dapat membantu mahasiswa baru melewati masa transisi ke dunia kampus. Hal tersebut dapat menjadi solusi bagi kasus-kasus cuci otak NII yang menyasar mahasiswa baru yang dilakukan melalui pendekatan personal. Melalui cara-cara deradikalisasi yang humanis dan toleran di dunia kampus, diharapkan kasuskasus radikalisme atas nama agama pada kalangan intelektual muda tidak terulang kembali di masa mendatang.

\section{SIMPULAN}

Kasus-kasus kekerasan atas nama agama menyasar semua lapisan masyarakat tanpa terkecuali. Tidak ada satu golongan masyarakat pun yang imun akan tindakan intoleransi, termasuk intelektual muda (mahasiswa). Mahasiswa sebagai kaum intelektual muda justru menjadi sasaran kelompok intoleran yang menyusup ke lingkungan kampus. Sampel dalam penelitian ini adalah 649 orang mahasiswa semester empat yang tersebar di kampus ITB, UNPAD, UPI, UIN Sunan Gunung Djati, UNPAS, UNISBA dan POLBAN pada tahun 2012. Kelengkapan data juga dikumpulkan melalui wawancara dengan pelbagai pihak terkait seperti Polrestabes Kota Bandung, Departemen Agama Kota Bandung, Kementerian Agama Kota Bandung, Ketua NII Crisis Center, Mahasiswa Mantan Anggota NII dan Aktifis kampuas.

Berdasarkan hasil penelitian, sebanyak $65 \%$ responden memiliki kesediaan mendengarkan, menghargai dan menerima perbedaan pendapat, serta memandang perbedaan sebagai kewajaran. Sebanyak 63\% responden menerima perbedaan dalam praktik peribadatan, memandang perbedaan agama sebagai hal yang lumrah serta menghargai pandangan bahwa semua agama mengajarkan kebenaran (nilai kemanusiaan sebagai nilai universal). Namun, masih terdapat tindakan-tindakan 
diskriminasi yang terkadang dilakukan oleh 32\% responden. Sebanyak 33\% responden kadang-kadang melakukan tindakan pemaksaan serta $5 \%$ responden memiliki pandangan kekerasan pada skala tinggi (selalu) dan 24\% skala sedang (kadang-kadang).

Berdasarkan hasil penelitian dapat disimpulkan bahwa, paradigma sosial dan keagamaan individu dapat mempengaruhi perspektif dan tindakan individu di masyarakat. Berkaitan dengan ini, hasil penelitian menunjukkan bahwa setengah dari responden (42\% cukup setuju dan $8 \%$ setuju) memiliki pandangan intoleran dan kebencian (mudah memandang kafir seseorang). Masih banyak mahasiswa sebagai kaum intelektual muda, memiliki perspektif jihad yang keliru memandang jihad identik dengan kekerasan (21\% cukup setuju dan 3\% setuju). Sebanyak 22\% responden cukup setuju dan 3\% setuju menerjemahkan jihad identik dengan terorisme. Selain itu, $15 \%$ responden cukup setuju dan $2 \%$ setuju memandang bom bunuh diri sebagai bentuk tindakan jihad. Mahasiswa sebagai intelektual muda sudah sepatutnya memiliki sudut pandang dan pemahaman konteks jihad yang benar dan tidak melenceng baik secara etimologi maupun epistemologi.

Radikalisme atas nama agama di kampus harus ditangani bersama antara pihak kampus, pemerintah, masyarakat umum, dan pihak-pihak terkait. Solusi yang dipilih harus bersifat konstruktif serta berangkat dari penyelesaian terhadap akar atau sumber masalah/core of the problems. Salah satu caranya melalui deradikalisasi untuk meluruskan pemahaman yang sempit melalui upaya yang ramah, toleran, damai dan manusiawi baik dalam bidang sosial, politik, ekonomi maupun pendidikan. Upaya deradikalisasi dalam bidang Pendidikan pada intelektual muda di dunia kampus dapat diterapkan baik dalam perkuliahan, diluar perkuliahan maupun dalam setiap kebijakan kampus yang mendukung terciptanya iklim kampus yang damai, toleran dan berwawasan multikultural. Hal tersebut merupakan upaya preventif dan persuasif dalam mencegah tumbuhnya paham-paham radikal di dunia kampus.

\section{REFERENSI}

Albone, A. A. (2006). Pendidikan Agama Islam dalam Perspektif Multikulturalisme. Jakarta: Balai Penelitian dan Pengembangan Agama Jakarta.

Ali M., A. (2011). Mahasiswa ITB Paling Banyak Direkrut Oleh NII. Retrieved 11 January 2021, from antaranews.com website: https://www.antaranews.com/berita/255837/mahasiswa-itbpaling-banyak-direkrut-oleh-nii\#: :text=Bandung (ANTARA News) - Mahasiswa,sudah sejak dulu digoyang NII.

Amirsyah. (2012). Meluruskan Salah Paham Terhadap Deradikalisasi: Pemikiran, Konsep dan Strategi Pelaksanaan. Jakarta: Penerbit Grafindo Khazanah Ilmu.

Azra, A. (2002). Konflik Baru Antar Peradaban: Globalisasi, Radikalisme dan Pluralitas. Jakarta: PT. Raja Grafindo Persada.

Azra, A. (2011). Rekrutmen Sel Radikal di Kampus. Retrieved 11 January 2021, from Kompas.com website:

https://internasional.kompas.com/read/2011/04/27/03003078/rekrutmen.sel.radikal.d i.kampus?page $=$ all

Bin-Saat, I. (2007). Radikalisme Melayu Dari Perak 1945-1970: Kebangkitan Rakyat, Pemikiran, Sumbangan dan Pengorbanan. Universiti Sains Malaysia.

Burhani, A. N. (2001). Islam Dinamis:Menggugat Peran Agama Membongkar Doktrin yang Membatu. Jakarta: Kompas.

Creswell, J. W. (1994). Research Design: Qualitative \& Quantitativ Approaches. London: Sage Publications.

Departemen Agama RI. (2003). Persatuan Kerukunan Umat Beragama. Jakarta: Depag RI. 
Hardiman, F. B. (2002). Belajar dari Politik Multikulturalisme. In Kewargaan Multikultur: Teori Liberal Mengenal Hal-Hak Minoritas. Jakarta: LP3ES.

Hasani, I. (2010). Radikalisme Agama di Jabodetabek \& Jawa Barat, Implikasinya terhadap Jaminan Kebebasan Beragama/Berkeyakinan. Jakarta: Publikasi SETARA Institute.

Hiariej, E. (2010). Aksi dan Identitas Kolektif Gerakan Islam Radikal di Indonesia. Jurnal Ilmu Sosial Dan Ilmu Politik, 14(2), 131-168.

Komalasari, K. (2008). Cooperative dan Self Regulated Learning: Esensi Pembelajaran Konstekstual dalam Pendidikan Kewarganegaraan di SMP Jawa Barat. JURNAL CIVICUS, 8(1). https://doi.org/10.17509/civicus.v8i1.26053

Mahfud, C. (2011). Pendidikan multikultural. Bandung: Pustaka Pelajar.

Naim, N. (2017). Pendidikan multikultural, konsep dan aplikasi (Vol. 1). Yogyakarta: Ar-Ruzz Media. Nasikun. (2007). Sistem Sosial Indonesia. Jakarta: PT. RajaGrafindo Persada.

Qardhawi, Y. (2009). Islam Radikal Analisis Terhadap Radikalisme dalam Berislam dan Upaya Pencegahannya. Yogyakarta: Era Adicipta Intermedia.

Sabirin, R. (2004). Islam dan Radikalisme. Jakarta: Penerbit Ar Rasyid.

Singh, B., \& Mulkhan, A. M. (2012). Jejaring Radikalisme Islam di Indonesia (Jejak sang pengantin bom bunih diri). Yogyakarta: Jogja Bangkit Publisher.

Sirry, M. A. (2002). Dilema Islam Dilema Demokrasi (Pengalaman baru muslim dalam transisi Indonesia). Bekasi: Gugus Press.

Sugiyono. (2011). Metode Penelitian Kuantitatif Kualitatif dan R\&D. Bandung: Bandung: Alfabeta.

Suryadinata, L., Arifin, E. N., \& Ananta, A. (2003). Indonesia's Population: Ethnicity and Religion in a Changing Political Landscape. Singapore: Institute of Southeast Asian Studies.

Suseno, F. M. (2006). Berebut jiwa bangsa: dialog, perdamaian, dan persaudaraan. Jakarta: Penerbit Buku Kompas.

Umar, A. R. M. (2010). Melacak akar radikalisme Islam di Indonesia. Jurnal Ilmu Sosial Dan Ilmu Politik, 14(2), 169-186.

Zubaedi. (2012). Islam dan Benturan Antarperadaban (Dialog Filsafat Barat dengan Islam, Dialog Peradaban dan Dialog Agama). Yogyakarta: Ar Ruzz Media. 